з іншого, - до економії мовних засобів і спрощення семантичної та структурної організації іхтіонімів. Практична цінність результатів дослідження полягає в можливості використання їх у практичній та теоретичній систематиці іхтіофауни України.

Ключові слова: номенклатура, термін, іхтіонім, варіант, синонім.

Tatiana F. SHUMARINA,

PhD (Philological Sciences), Associate Professor of the Russian Language Department of Odessa I. I. Mechnikov National University;

24/26 Francuzskij blvd., Odessa, 65058, Ukraine; e-mail: shumarina2010@mail.ru;

tel.: +38(048)683539; mob.: +38 067 3779936; ORCID ID: 0000-0001-7383-7707

\title{
NOMENCLATURE SYNONYMS AND VARIANTS OF TAXONS IN THE ICHTHYOLOGICAL SYSTEMATICS (ON THE MATERIAL OF THE NAMES OF FISHES OF UKRAINE)
}

Summary. The article describes the terminological vocabulary used in modern Ukrainian and Russian Ichthyological taxonomies. The purpose of this article is to identify current trends in the national language (Russian and Ukrainian) taxonomies. The object of study in the present work was the biological nomenclature; research subject - the nomenclature nominations of fishes of Ukraine. Descriptive and comparative methods were used. As a result, the study identifies variants and synonyms of the terms, the similarities and differences in vernacular nominations of fish. Conclusions. The presence of an absolute and partial synonyms, as well as the variance in both languages due to extralingual and intralingual factors. Modern processes of unification and standardization of fish names complicated due to the presence of two conflicting trends. Onomasiological trends in national systems of ichthyological terms are contradictory: on the one hand, this is an attraction to the analytical word formation, and on the other - to save linguistic resources and simplify the semantic and structural organization of these terms. The practical value of the results of the study lies in the possibility of their use in practical and theoretical taxonomy of the fish fauna of Ukraine.

Key words: nomenclature, the term, ichthyonym, variant, synonymous.

Статтю отримано 22.09.2017 p.

http://dx.doi.org/10.18524/2307-4558.2017.28.115844

УДК [811.161.1+811.163.2+811.14'06]'367.4'373.611/.612

КЂНЕВА Виктория Гочева,

доктор по филология, главен асистент, катедра „Класически и източни езици и култури“,

Великотърновски университет „Св. св. Кирил и Методий“; гр. Велико Търново, 5003, България; тел.: +359 885149 429; e-mail: vgotcheva_g@mail.bg; ORCID ID: 0000-0003-1103-3054

\section{СЪКРАТЕНИТЕ НОМИНАТИВНИ ЕДИНИЦИ В КОНТЕКСТА НА ОТНОШЕНИЯТА „ЕКВИВАЛЕНТНОСТ - БЕЗЕКВИВАЛЕНТНОСТ“. УНИВЕРБИЗАЦИЯ (ВЪРХУ МАТЕРИАЛ ОТ БЪЛГАРСКИЯ, РУСКИЯ И ГРЪЦКИЯ ЕЗИК)}

Анотация: Целта на настоящата статия е анализ на универбизацията в светлината на отношенията еквивалентност - безеквивалентност. Обект са универбатите от гледище на ролята им за появата на лакуни в руския, българския и гръцкия език. Основен метод на изследване е съпоставителният. Резултатите от анализа показват, че спецификите, които притежава всеки от трите езика, неминуемо водят до разлики както в граматичните, така и в лексикалните им системи. Съпоставката и анализът на универбатите на трите сравнявани езика дава представа за възприемането и интерпретирането на фактите от реалната действителност от страна на всеки един от тези три народа. Основният извод е, че универбизацията като явление, обусловено от екстралингвистични фактори и зависещо изцяло от конкретните езикови средства, в определени случаи е причина за констатирано наличие на „бели петна“при езикова съпоставка и/или превод. Практическото значение на представения анализ е свързано преди всичко с теоретичните и практическите проблеми на превода. език.

Ключови думи: универбизация, еквивалентност, безеквивалентност, лакуна, руски език, български език, гръцки

Поставяне на проблема. Формирането на нови понятия, отразяващи новопоявили се предмети, явления или обществени отношения, води до необходимост от тяхното назоваване и съответно от създаване на нови номинативни единици ${ }^{1}$, които да запълват „празните места“в речниковия състав на съответния език.

${ }^{1}$ За понятието номинативна единица и за неговото разбиране, както и за видовете номинативни единици вж. [8]. 
Създаването на нови номинативни единици става на базата на съществуващите езикови средства. В тази връзка трябва да бъдат отчетени на първо място ограничеността на езиковите ресурси и на второ място -тенденцията към икономия на езиковите средства (или „езикова икономия“по О. Есперсен), а също и принципа за спестяване на психо-фозичната енергия при артикулационните движения, свързан със стремежа за по-голямо удобство при учленяването на звуковете в потока на речта (или „закон за икономия на езиковите усилия“по А. Мартине) [3, с. 15].

Всяка нова номинация се извършва по аналогия и най-често се използват готови в езика словообразувателни модели, като се спазват общозадължителните вътрешноезикови закономерности, които гарантират правилното функциониране на езиковата система.

При номинацията ${ }^{1}$ могат да бъдат проследени две противоположни тенденции: обединяване на самостоятелни номинативни единици в нови единства ${ }^{2}$ и съкращаване на вече съществуващи такива, тяхното „свиване“до еднословни номинативни единици с тъждествено семантично съдържание ${ }^{3}$.

Възможностите за образуване на съкратени форми от многословни номинативни единици, както и конкретните начини за тяхното съкращаване, които във всеки език имат своя собствена специфика, представляват немаловажна предпоставка за поява на лакуни в даден език при сравнение с друг. Съкратеното представяне на тези единици се извършва по два начина - чрез универбизация и чрез абревиация.

Поставяне на задачите. Цел на настоящата статия е разглеждането на универбизацията в светлината на отношенията еквивалентност - безеквивалентност ${ }^{4}$ В тази връзка ще се опитаме: а) да проследим основните разбирания за универбизацията и начините на тяхното възникване; б) да анализираме тези начини от гледище на ролята им в появата на лакуни в руския, българския и гръцкия език.

\section{Ивложение на основния материал.}

1. Универбизация и начини на универбизиране. В научната литература терминът универбизация е тълкуван по немалко различни един от друг начини. В зависимост от съдържанието, влагано в това понятие, в състава на универбатите се включват много и различни по своя характер явления. Дефинициите на различните автори варират от доста широко до твърде тясно разбиране за явлението.

А. Исаченко, който въвежда този термин, разбира универбизацията като „сгъстяване на семантичното съдържание в една дума“"[5, с. 338], а процесите, свързани с елиминирането на семантичната разчлененост, той нарича семантична кондензация. Авторът влага в термина универбизация твърде широк смисъл, включвайки композицията, сливането, елиптичните пропуски на един от елементите в съчетанието, афиксалната деривация, загубата на граматичното оформяне на първия компонент при съчетания от типа жар-nтuщa, а също и различните видове абревиатури [5, c. 340-342].

Широкото разбиране е застъпено и в работите на Е. Земска, която приема универбизацията като „начин за образуване на дума на базата на словосъчетание, при който в производната дума се включва основата единствено на един от компонентите на словосъчетанието, така че по форма производното се съотнася с една дума, а по смисъл - с цялото словосъчетание“[4, с. 109]. Според Й. Калишан, предложената дефиниция е неточна, тъй като липсата на ограничения на типа словосъчетания, от които се образуват универбатите, не само че разширява изключително много границите на явлението, но и води до отъждествяването му с деривацията. Авторът счита, че за универбизация може и трябва да се говори само ако новото образувание възниква на базата на устойчиво разделно оформено наименование, независимо дали последното е двусловно или съдържа повече компоненти. С други думи, универбизацията е процес на замяна на устойчиво аналитично оформено название, функционално равносилно на дума, с омосемично еднословно наименование $[6$, c. 405].

М. Виденов, от своя страна, определя универбизацията като „свеждане на многословни структури към еднословни“и я разглежда в широк и в тесен смисъл. В първия случай в състава на универбатите попадат инициалните и сричковите съкращения, някои съставни названия от типа албба-изливане, бета-лъчение и субстантивираните прилагателни. Във втория случай, като същинска универбизация или универбизацията в тесния смисъл, М. Виденов определя „наименованията, кои-

\footnotetext{
1 Четирите основни начина, по които се осъществява номинацията, извършвана на базата на съществуващ езиков материал, са: (1) семантична номинация; (2) деривация; (3) композиция и синапсий; (4) съкращаване.

${ }^{2}$ Става въпрос за номинативни единици, образувани посредством съчетаването на два и повече компонента, чиито лексикални значения се свързват в семантично единство, т.е. в случаите, когато номинацията се осъществява чрез композиция и синапсий.

${ }^{3}$ Това са номинативни единици, образувани посредством преобразуване в нови по-компактни езикови образувания, т.е. номинацията се извършава чрез съкращаване.

${ }^{4}$ Абревиауията в контекста на на отношенията еквивалентност - безеквивалентност при превод сме разгледали в доклада си „Сокращенные номинативные единицы в контексте отношений эквивалентности - безэквивалентности. Аббревиация (на материале болгарского, русского и греческого языков)“, изнесен на юбилейната международна научна конференция „Русистика - вчера, сегодня, завтра“(29 юни - 02 юли 2017 г.), проведена в гр. София, България, който към настоящия момент е под печат.
} 
ISSN 2307-4558; ISSN 2414-9489. Мова. 2017. № 28

то са получени от словосъчетание прилагателно + съществително, опростено до една съставка, дооформена по някои от словообразувателните модели на езика“"[2, с. 29-30].

Според В. Мурдаров, универбизацията се осъществява чрез съкращаване на формата при запазване на семантиката на съчетанието, от което се образува, т.е. „процесът протича единствено на формално, но не и на семантично равнище" $[9$, с. 114].

Тясното разбиране е възприето и в изследването на Д. Благоева, която приема, че това е процес на „преобразуване на съставни лексикални единици (номинативни словосъчетания) с бинарна структура (определяемо и атрибут) в еднословни единици с тъждествено семантично съдържание“[1, с. 6]. Авторката, като изхожда от разработката на В. Мурдаров [9, с. 116-119], отделя три структурни типа универбизация, осъществявана със средствата на 1) морфологичното словообразуване, 2) морфолого-синтактичното словообразуване и 3) лексикално-семантичното словообразуване $[1$, c. $7-17]$.

1. Първият тип универбати се образуват чрез прибавяне на суфиикси и чрез нулева суфиксация. „При суфиксалната универбизация субстантивният компонент в изходното номинативно словосъчетание (експонент на родовото понятие) се отстранява, а от атрибутивния (експонент на видовия признак) се образува съществително универбат чрез прибавяне на суфикс“, напр. бълг. есенни култури = есенничи, марирутно такси = марирутка, патрулна кола = патрулка, сапунена опера $=$ сапунка; рус. валютный магазин $=$ валютка, минеральная вода $=$ минералка, многоэтажное здание = многоэтажка, фруктовое мороженое = бруктовка.

При универбатите, образувани чрез нулева суфиксация, „основата на адективния компонент в изходното номинативно словосъчетание се подлага на дезинтеграция, без да се добавя наставка. Дезинтеграцията протича чрез отстраняване на суфикс"(кабелна телевизия = кабел, дънна платка $=$ дъно, автоматична пушка = автомат и др.) [1, с. 7, 14]. Срв. рус.противогазовая маска= противогаз, декретный отпуск = декрет.

2. Вторият тип универбизация, субстантивацията, се осъществява чрез средствата на морфолого-синтактичното словообразуване. Честата употреба в речта на някои словосъчетания постепенно води до самостойната употреба на определящия елемент и той започва да изпълнява функцията на определяемото (т.е. на съществителното).По този начин се образуват субстантивираните прилагателни и причастия, които приемат характеристики на съществително, напр. права линия = права, гостна стая = гостна.

В по-голямата част от случаите субстантивацията е зависима от конкретния контекст, т. е. универбатите са контекстуално обусловени субстантивирани прилагателни: бълг. детски [надбавки];

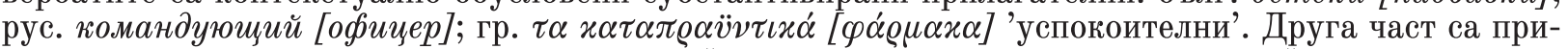
лагателни, изпълняващи в дадена ситуация функцията на съществителни: напр. филмови заглавия от типа на „Добрият, лошият и злият“, „Богат-беден“. Едва една малка част от прилагателните и причастията се субстантивират напълно и се превръщат в самостоятелни, независещи от контекста,

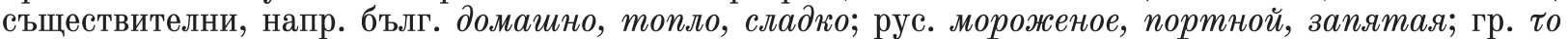

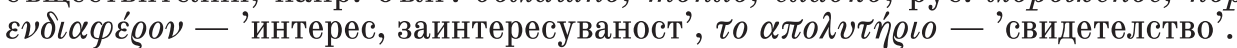

Субстантивацията като начин на съкращаване на материалната форма на номинативната единица, трябва да се различава от използването на субстантивираните прилагателни и причастия като модел за образуване на нови съществителни, служещи за попълването на липсващи звена в дадена словообразувателна парадигма. Срв. частно, делимо, неизвестно в българския език или пирожковая, пилотская в руския, които не са резултат от субстантивация, а са образувани по модела, заложен от изградените вече в езика субстантивирани номинативни единици.

3. Последният тип универбати се образуват с помощта на лексикално-семантичното словообразуване. За разлика от субстантивацията, тук се наблюдава отпадане на атрибутивния компонент, при което „стесненото понятие се изразява чрез една проста дума, обогатена по лексико-семантичен признак“"[10, с. 86], т. е. налице е процес на формиране на ново лексикално значение у съществителното, което вече обозначава цялото понятие. Напр. бълг. електрически ток = ток, атомен реактор $=$

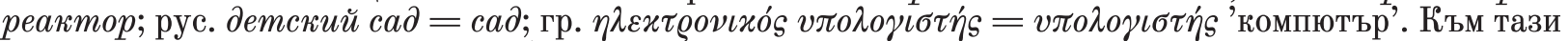
група спадат също така и универбати, получени чрез декомпозиция на сложни думи, лексикални съкращения или фразеологични единици: напр. бълг. вратоврвзка=врвзка, кожа-кола= ко́ла, говоря като кречетало $=$ кречетало; резус-дбактор $=$ резус; рус. медсестра = сестра. Разновидност на този тип универбати са и съкращенията на генитивни конструкции в руския и гръцкия език: напр.

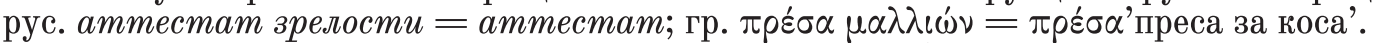

Въз основа на гореизложеното, приемаме, че универбизациятае явление, породено от стремежа към икономия на езиковите средства, усилия и време и представлява начин за вторична номинация, извършвана посредством преобразуване на съставни номинативни единици, „независимо от граматичната им структура и степен на сложност“[6, с. 408], в номинативни единици с по-компактна форма и с тъждествено семантично съдържание. На универбизация са подложени предимно устойчивите словосъчетания, но не е изключено и образуването на универбати от фразеологични съчетания, сложни думи и свободни словосъчетания, които преминават етап на съставни наименования. 
C течение на времето, след като се е утвърдила в езиковата практика, за дадената съставна номинативна единица се търси по-кратка и икономична форма за изразяването на нейното съдържание. За тази цел, веднъж назованото по два (а понякога, макар и по-рядко, повече) свои най-очебийни признака понятие, бива преназовано посредством съкращаване на формата и съпроводено от семантична кондензация, при което един от компонентите приема значението и функциите на цялата съставна номинативна единица, а другият компонент формално е игнориран. По този начин езикът елиминира „вътрешното противоречие между разделно оформеното название и единството на неговото значение“"[5, с. 339].

А. Исаченко обръща внимание на факта, че в много случаи при възникването си новото понятие не се назовава направо, а по-скоро се описва, като стадият на описване на наименованието при нормални условия, рано или късно се преодолява [5, с. 339-340]. На този етап от съществуването си съставната номинативна единица и образуваният от нея универбат се използват паралелно и са взаимозаменяеми, тъй като последният все още се възприема от носителите на езика като единица, съвместяваща лексикалните значения и функциите на съставната номинативна единица, от която произлиза.Например на съвременния етап от съществуването си съчетанието маршрутно такси е равно по значение и функция на съществителното маршрутка. В бъдеще, обаче, има голяма вероятност маршрутка да се възприема като производна номинативна единица (дериват) със съвсем очевидна вътрешна форма, а сложното название марирутно такси вече да не е в активна употреба. Такъв е случаят със съществителното химикалка, образувано посредством универбизация от съчетанието химикална писалка. Понастоящем връзката между двете единици е напълно заличена. Срв. още: пзрвак= пғрва ракия или пък моторница, която все по-рядко се свързва със съчетанието, от което е произлязло (моторна лодка). В руския език чрез универбизация са образувани например такива съществителни като перчатки = перщатые рукавицы или индюк и индейка, съответно от индейский петух и индейская курица, които носителите на съвременния руски език вече не възприемат като равноправни на съчетанията, от които произлизат и съответно като взаимозаменяеми в речта единици ${ }^{1}$.

Казаното дотук ни дава основание от гледна точка на съвременното състояние на езика да считаме универбатите за вид съкращения, паралелно съществуващи със съставните номинативни единици, от които произлизат, но с оглед на бъдещото развитие и състояние на езика, повечето от тях най-вероятно ще бъдат приемани като обикновени производни номинативни единици. С други думи, при универбатите се наблюдава процес на преобразуване на номинативните единици от съставни в несъставни, който най-често предстои да бъде приключен.

2. Универбизацията в контекста на отношенията еквивалентност - бевеквивалентност.

Процесът на универбизация до голяма степен е обусловен от външноезикови фактори, но самите начини за образуване на универбати изцяло зависят от средствата, с които разполага съответният език. В даден език този процес може да се е развил по отношение на определена част от съставните номинативни единици, докато в друг език няма подходящите условия за такова развитие. По този начин на универбат от един език в друг език може да отговаря словосъчетание, тъждествено по съдържание на това, с което се съотнася в семантичен план съответният универбат.

Въпреки че голяма част от универбатите принадлежат към разговорната реч, една част от тях са навлезли вече в книжовния език, а друга част, поради своята икономичност, постепенно се налагат и тепърва най-вероятно ще навлизат в речниковия фонд. И в трите езика най-често подлежат на универбизация атрибутивните безпредложни съчетания и много по-рядко атрибутивните предложни, тъй като при първите необходимостта от съгласуване между определящия и определяния компонент прави техните значения в много по-голяма степен зависими едно от друго, за разлика от вторите, при които се наблюдава по-голяма самостоятелност на компонентите, влизащи в състава на названието. Подобно съкращаване на формата, съпроводено от семантична кондензация, може да бъде наблюдавано и при сложните думи, напр. рус. рыболов $=p$ ьбалк $a^{2}$.

Процесите на универбизация са изключително характерни за руския език, където „непрекъснато биват създавани неофициални названия за битовата и професионалната реч като заместители на официалните названия“[9, с. 120]. Най-активна и най-силно е застъпена суфиксалната универбизация. Голямото разнообразие от руски суфикси, използвани за тази цел,предполага и голям брой номинативни единици, образувани по този начин ${ }^{3}$ и в много случаи става причина за липсата на съответствия в другите два езика. Пример за това са руските универбати, като незавериёнка= незавериённое строительство, недостроенное здание; коммуналка = коммунальная квартира и др., които в българския език съответно се предават като недовгршен обект и апартамент, в който жи-

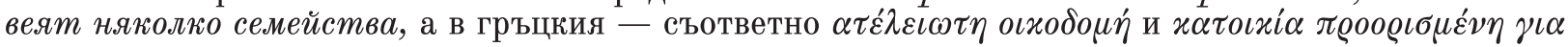

\footnotetext{
${ }^{1}$ Вж.[5, с. 340$]$, откъдето са руските примери.

${ }_{2}$ Срв. [5, с. 340-341]. Според А. Исаченко, резултат от семантична кондензация са също така и номинативните единици, образувани чрез композиция: напр. руското местожительство е образувано от съчетанието жесто жительства или накануне, съответно от на жануне. Иначе казано, от негова гледна точка, сложните думи също са резултат от семантична кондензация - мнение, с което трудно може да се съгласим.

3 Вж. [1, c. 5-21].
} 
ISSN 2307-4558; ISSN 2414-9489. Мова. 2017. № 28

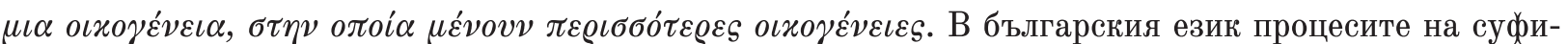
ксална универбизация са по-малко застъпени, в гръцкия език обаче суфиксалната универбизацияе

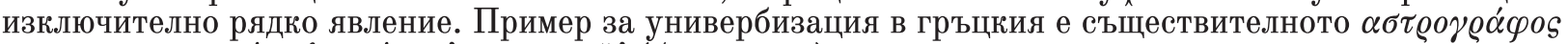

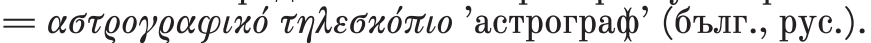

И за трите разглеждани езика субстантивацията на прилагателни и причастия е характерно явление. Много често получените чрез субстантивация съществителни в единия от езиците имат като съответствия в другите два или аналогично образувани субстантивирани съществителни (сла-

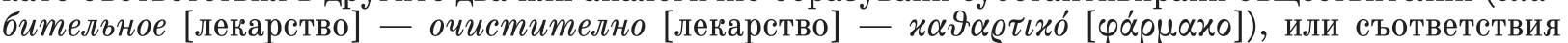
под формата на несубстантивирана самостоятелна номинативна единица (мороженое - сладолед $-\pi \alpha j \omega \tau o ́)$. Ако в някой от езиците има „бяло петно“, то обикновено няма връзка с възможностите за субстантивация - напр. рус. штатское в българския език се предава като уивилно облекло. Само в отделни случаи се наблюдава липса на съответствие, имащо пряка връзка със самия начин на образуване на съкратени названия.Такъв пример е цяла група прилагателни от ср. р. мн. ч. в гръцкия език,завършващи на - жк,със значение 'разходи, такси, заплащане', които се субстантивират по един и същи модел. Честотата на употреба на образуваните по този начин съществителни, превръща този завършек в изключително продуктивен модел за създаване на нови номинативни единици с такова значение. Отсъствието в руския и българския език на тъждествен модел води и до отсъствие на еднословни съответствия, т. е. тази лексика също се явява безеквивалентна по от-

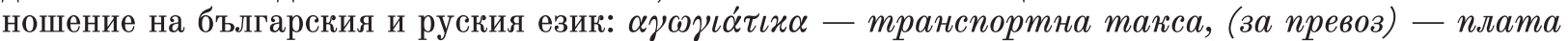

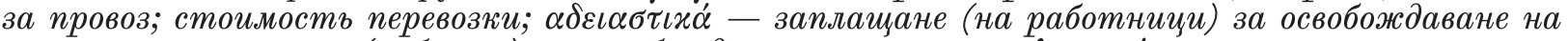

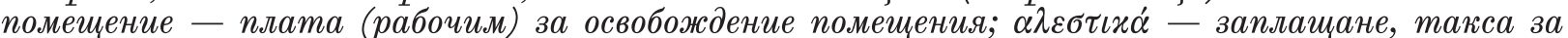

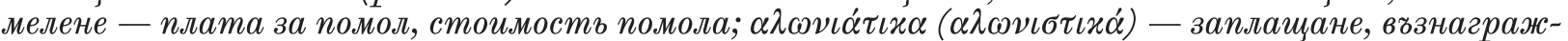

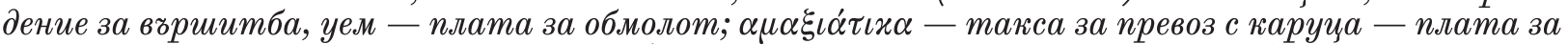
перевозку, стоимость перевозки; $\alpha \mu \pi \varepsilon \lambda \iota \alpha ́ \tau \iota x \alpha$ - налог за лозе; заплащане за работа по лозе или за

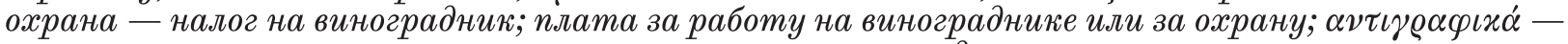
заплащане, такса за преписване, копиране, копирни разходи - плата за переписку, за копиров-

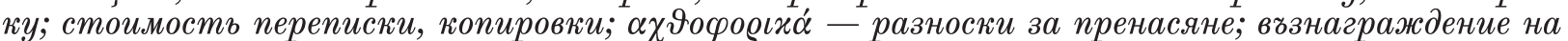

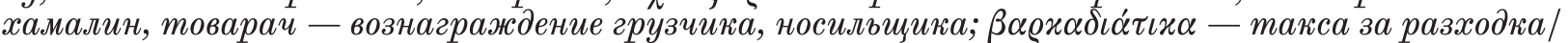

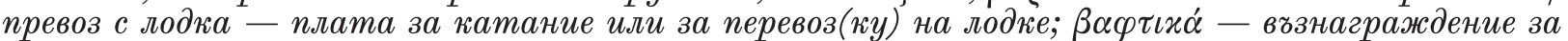

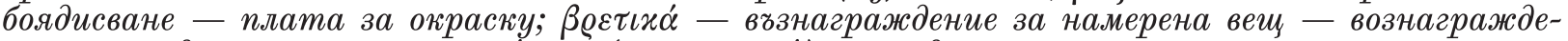

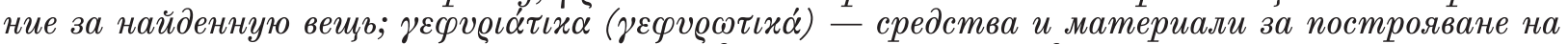
мост; такса за преминаване по мост - средства и материалы для постройки моста; пошлина

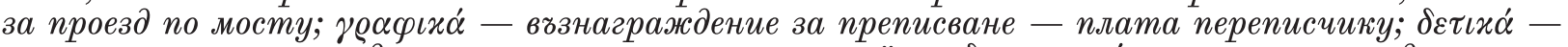

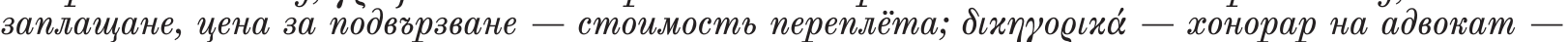

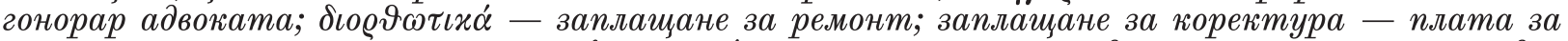

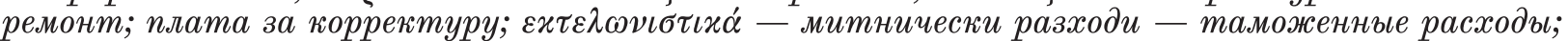

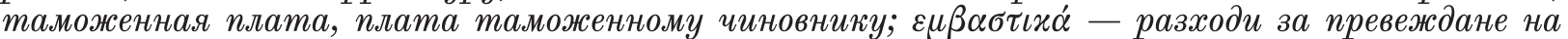

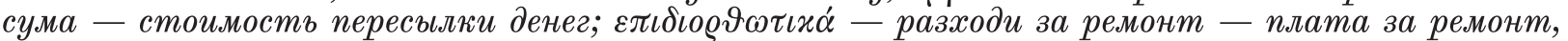

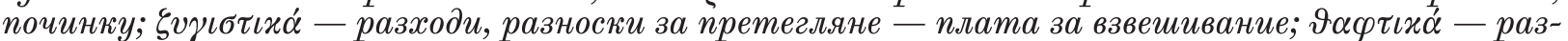

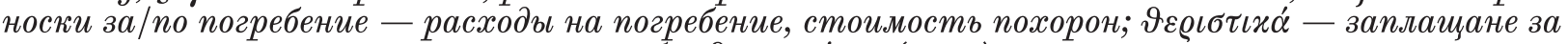

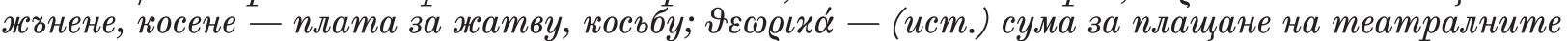

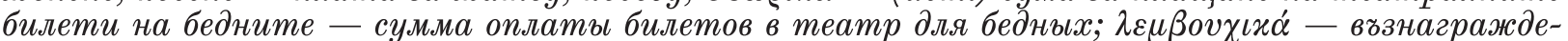
ние на лодкар за превоз - плата лодочнику за перевоз; доvбтьха́ - такса за къпане - плата за

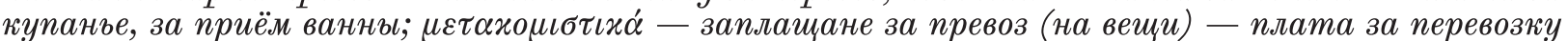

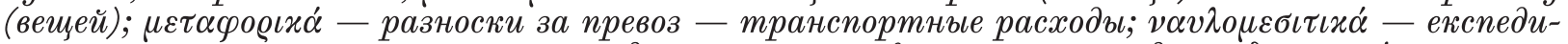

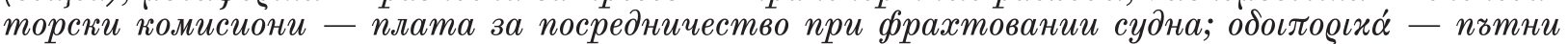

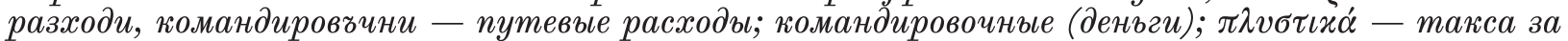

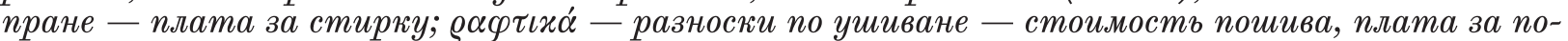

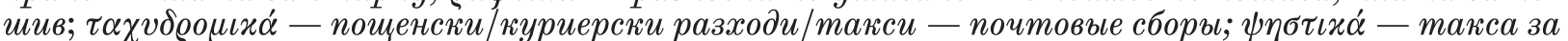
печене взв фбурна (за хляб, плодове) - плата за выпечку (в пекарне).

Очевидно е, че наличието на толкова голям брой аналогични по своето образуване и със сходна семантика съществителни се дължи на наложилия се в даден момент образец, като липсата на съответствия е следствие не толкова от невъзможността за субстантивация в руския и българския език, а по-скоро е резултат от продуктивността на дадения езиков модел за гръцкото словопроизводство.

Изводът, който може да бъде направен е, че в изследваните три езика субстантивацията като езиково явление сама по себе си не е толкова решаващ фактор за появата на лакуни, какъвто е например суфиксалната универбизация в руския език.

И в трите изследвани езика универбатите, образувани посредством лексикално-семантично словообразуване, са характерни предимно за разговорната реч. Това е и причината липса на съответствия във вид на самостоятелна номинативна единица на този вид универбати да се констатира не толкова при междуезикова съпоставка, колкото при превод (и то предимно при превод на художествена литература), тъй като дори и за употребата на тези универбати в езика на оригинала в повечето случаи се изисква по-широк контекст. Въпреки това и тук могат да бъдат наблюдавани случаи 
на липса на еквивалент при превод на цели групи такива съкратени единици. Пример за това могат са послужат руските съчетания от прилагателното больной и съществителни, обозначаващи част от тялото или орган (печень, сердие, почки, ноги, руки, глаза, голова, уши, горлои т.н.) ${ }^{1}$ : У неё уже три года гландъ; У тебя зуб?; У отца нервы, а у мамы желудож. В цитираните примери няма еквивалент във вид на самостоятелна номинативна единица и съответно преводът и в българския, и в гръцкия език е свободно словосъчетание - Вече три години има болни сливичи; Болен зъб ли имаш? / Ззб

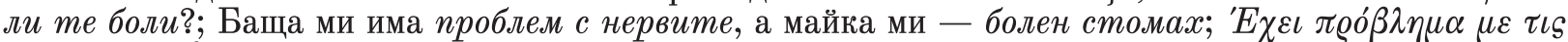

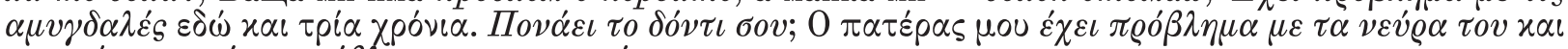

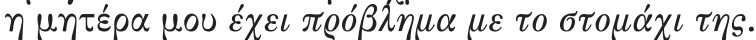

Изводи. В заключение можем да отбележим, че спецификите, които притежава всеки от трите езика неминуемо водят до разлики както в граматичните, така и в лексикалните им системи. Съпоставката и анализът на универбатите на трите сравнявани езика разкрива различията при отразяването на понятията, дава представа за възприемането и интерпретирането на фактите от реалната действителност от страна на всеки един от тези три народа.

Имайки предвид всичко казано по-горе, можем да твърдим, че универбизацията като явление, обусловено от екстралингвистични фоктори и зависещо изцяло от конкретните езикови средства, в определени случаи е причина за констатирано наличие на „бели петна“при езикова съпоставка и/ или превод.

\section{Литература}

1. Благоева Д. Универбизацията в най-новото славянско словообразуване (върху материал от българския, руския и чешкия език) / Д. Благоева // Съпоставително езикознание. - София, 2003. - № 3. - С. 5-21.

2. Виденов M. Универбизацията - присъща черта на българския разговорен стил / М. Виденов // Език и литература. - София, 1976. - № 4. - С. 28-35.

3. Граматика на съвременния български жнижовен език : т. 2. Морфология. - София : БАН. 1983. - 511 с.

4. Земская E. A. Русская разговорная речь : лингвистический анализ и проблемы обучения / Е. А. Земская. М. :Русский язык, 1979. - 240 с.

5. Исаченко A. B.К вопросу о структурной типологии словарного состава славянских литературных языков / A. В. Исаченко // Slavia. - Praha, 1958. - № 3. - C. 334-352.

6. Калишан $E$. К уточнению понятия универбации (на материале русского языка) / Е. Калишан // Slavia Orientalis. - Warszawa : PWN, 1984. - № 3-4. - C. 401-408. 461.

7. Капанадзе Л. А. Номинация /Л. А. Капанадзе // Русская разговорная речь. - М. : Наука, 1973. - С. 403-

8. Кынева B. О термине “номинативная единица” в контексте исследования лексической безэквивалинтности (на материале русского, болгарского и греческого языков) / В. Кынева // Десятый международный симпозиум МАПРЯЛ 2010 «Теоретические и методические проблемы русского языка как иностранного в традиционной и корпусной лингвистике (доклады и сообщения)». - Велико-Тырново, 2011. - С. 103-114.

9. Мурдаров Вл. Съвременни словообразувателни процеси : очерк върху българското словообразуване / Вл. Мурдаров. - София : Наука и изкуство, 1983. - $244 \mathrm{c.}$

10. Пернишка E. За системността в лексикалната многозначност на съществителните имена / Е. Пернишка. София : БАН, 1993. - 274 с.

\section{References}

1. Blagoeva, D. (2003), "Univerbationin contemporary Slavic word-formation (based on Bulgarian, Russian and Czech language material)”, Contrastive Linguistics ["Univerbizacijata v naj-novoto slavjansko slovoobrazuvane (vyrhu materialot bylgarskija, ruskija i cheshkija ezik)", Sypostavitelno ezikoznanie], Sofia, vol. 3, pp. 5-21.

2. Videnov, M. (1976), "Univerbation - a typical feature of colloquial Bulgarian", Language and Literature ["Univerbizacijata - prisyshcha cherta na bylgarskija razgovoren stil", Ezik i literatura], Sofia, vol. 4, pp. 28-35.

3. Grammar of Contemporary Literary Bulgarian : vol. 2, Morphology (1983), [Gramatika na syvremennija bylgarski knizhoven ezik: t. 2. Morfologija], Bulgarian Academy of Science, Sofia, $511 \mathrm{p}$.

4. Zemskaja, E. A. (1979), Russian colloquial speech : linguistic analysis and issues in teaching [Russkaja razgovornaja rech': lingvisticheskij analiz i problem obuchenija], Russian language, Moscow, 240 p.

5. Isachenko, A. V. (1958), "On the question of structural typology of the vocabulary of Slavic literary languages", Slavia ["K voprosu o strukturnoj tipologii slovarnogo sostava slavjanskikh literaturnykh jazykov", Slavia], Praha, vol. 3, pp. 334-352.

6. Kalishan, E. (1984), "Towards a more precise definition of the term univerbation (based on Russian language material)", Slavia Orientalis ["K utochneniju ponjatija univerbacii (na material russkogo jazyka)", Slavia Orientalis], PanstwoweWydawnictwoNaukowe, Warszawa, vol. 3-4, pp. 401-408.

7. Kapanadze, L. A. (1973), "Nomination", Russian colloquial speech ["Nominacija", Russkaja razgovornaja rech'], Nauka, Moscow, pp. 403-461.

8. Kaneva, V. (2011), "On the term 'nominative unit' in the context of lexical non-equivalence (based on Russian, Bulgarian and Greek language material)", Tenth international symposium MAPRYAL 2010: Theoretical and methodological issues in Russian as a foreign language in traditional and corpus linguistics (reports and talks)" ["O termine 'nominativ-

${ }^{1}$ Примерът е по [7, с. 421-422]. 
naja edinica $\mathrm{v}$ kontekste issledovanija leksicheskoj bezekvivalentnosti (na materiale russkogo, bolgarskogo i grecheskogo jazykov)", Desyatyj mezhdunarodnyj simpozium MAPRYAL 2010 : Teoreticheskie $i$ metodicheskie problemy russkogo jazyka kak inostrannogo $v$ tradicionnoj i korpusnoj lingvistike (doklady $i$ soobshchenija)], Veliko Turnovo, pp. 103-114.

9. Murdarov, V. (1983), Contemporary word-formation processes : an outline of Bulgarian word-formation [Syvremenni slovoobrazuvatelni procesi : ocherk vyrhu bylgarskoto slovoobrazuvane], Nauka i izkustvo, Sofia, $244 \mathrm{p}$.

10. Pernishka, E. (1993), On the systematicity of the lexical polysemy of nouns [Zasistemnostta $v$ leksikalnata mnogoznachnost na syshchestvitelnite imena], Bulgarian Academy of Science, Sofia, 274 p.

КЫНЕВА Виктория Гочева,

кандидат филологических наук, главный ассистент кафедры классических и восточных языков и культур, Велико-Тырновский университет Святых Кирилла и Мефодия; Велико Тырново, 5003, Болгария; тел.: +359 885149 429; e-mail: vgotcheva_g@mail.bg; ORCID ID: 0000-0003-1103-3054

\section{СОКРАЩЁННЫЕ НОМИНАТИВНЫЕ ЕДИНИЦЫ В КОНТЕКСТЕ ОТНОШЕНИЙ „ЭКВИВАЛЕНТНОСТЬ - БЕЗЭКВИВАЛЕНТНОСТЬ). УНИВЕРБАЦИЯ (НА МАТЕРИАЛЕ БОЛГАРСКОГО, РУССКОГО И ГРЕЧЕСКОГО ЯЗЫКОВ)}

Аннотация. Цель статьи - проанализировать конструкции универбов в свете отношений эквивалентности безэквивалентности. Объектом изучения являются универбы, которые есть в одном или нескольких языках, а в других языках вместо аналогичного слова употребляется словосочетание, которое не подверглось универбации. Основным методом исследования является контрастивный анализ. Результаты анализа показывают, что специфика каждого из трёх языков неизбежно приводит к выявлению различий в их грамматической и лексической системах. Анализ универбов трёх сравниваемых языков даёт представление о восприятии и интерпретации фактов реальной жизни каждым народом - носителем того или иного языка. Основной вывод заключается в том, что универбация как явление, обусловленное внеязыковыми факторами и полностью зависимое от конкретных лингвистических средств, нередко становится причиной переводоведческих сложностей, когда слово соответствует в другом языке словосочетанию и наоборот.

Ключевые слова: универбация, эквивалентность, безэквивалентность, laquan, русский, болгарский, греческий языки.

Viktoriya G. KANEVA,

$\mathrm{PhD}$ in Philology, Senior Lecturer, Department of Classical and Eastern Languages and Cultures, St. Cyril and St. Methodius University of Veliko Turnovo; VelikoTurnovo, 5003, Bulgaria; tel.: +359 885149 429; e-mail: vgotcheva_g@mail.bg; ORCID ID: 0000-0003-1103-3054

\section{ABBREVIATED NOMINATIVE UNITS IN THE CONTEXT OF THE EQUIVALENCE - NON-EQUIVALENCE RELATIONSHIPS. UNIVERBATION (BASED ON BULGARIAN, RUSSIAN AND GREEK LANGUAGE MATERIAL)}

Summary. Purpose of the present article is the analysis of univerbation in the light of the equivalence - non-equivalence relationships. The object of the study are univerbations in terms of their role in the appearance of lacunae in Russian, Bulgarian and Greek. The main method of the study is contrastive analysis. The results show that the specificities of the three languages inevitably lead to differences in their grammatical as well as lexical systems. The contrast and analysis of the univerbations of the three languages in question gives an idea of the perception and interpretation of real-world facts from the point of view of each of the three peoples. The main conclusion is that univerbation as a phenomenon, which is conditioned by extra-linguistic factors and is completely dependent on the specific linguistic resources, in certain cases brings into existence the 'gaps' notable during contrastive analysis and/or translation. The practical significance of the present analysis is related above all to issues in translation theory and practice.

Key words: univerbation, equivalence, non-equivalence, lacuna, Russian, Bulgarian, Greek.

Статтю отримано 28.09.2017 $p$. 